\title{
The Impact of Goodwill Recognition and Goodwill Impairment on the Increasing Holdings of Block Shareholders
}

\author{
Xiaofang Tan $\left(\mathbb{D}\right.$, Xin Ge $\mathbb{D}^{D}$, Qinghua Liu $\mathbb{D}$, and Zhengjun Yuan $\mathbb{1}$ \\ School of Maritime Economics and Management, Dalian Maritime University, Dalian 116026, China \\ Correspondence should be addressed to Xiaofang Tan; dlmutxf@dlmu.edu.cn
}

Received 13 May 2021; Revised 13 July 2021; Accepted 5 November 2021; Published 23 November 2021

Academic Editor: Lei Xie

Copyright (C) 2021 Xiaofang Tan et al. This is an open access article distributed under the Creative Commons Attribution License, which permits unrestricted use, distribution, and reproduction in any medium, provided the original work is properly cited.

\begin{abstract}
There is a large amount of goodwill recognition and goodwill impairment. These characteristics would trigger stock price fluctuation. Hence, stakeholders will increase holdings to mitigate the volatility of stock prices. According to the data in regard to the Chinese A-share nonfinancial listed companies from 2007 to 2020, we study the reaction of block shareholders after goodwill recognition and goodwill impairment, respectively. Our findings are as follows: (1) goodwill recognition leads to increasing holdings of block shareholders; (2) goodwill impairment also leads to increasing holdings of block shareholders when there is a large amount of goodwill impairment. We also take state ownership into consideration: compared to state-owned firms, private firms show a much stronger positive relation between goodwill recognition and level of increasing holdings of block shareholders, but there is no significant relation between goodwill impairment and increasing holdings of block shareholders in state-owned firms. These empirical results provide us with abundant evidence that block shareholders would increase shareholdings when there is goodwill recognition due to private information of positive future expectation in M\&A. Meanwhile, block shareholders would stabilize stock price via increasing shareholdings when goodwill is impaired.
\end{abstract}

\section{Introduction}

Goodwill refers to the difference between the consideration paid by the listed company in the process of acquiring the target asset and the fair value of the identifiable net assets of the acquired party. During the accounting period when the merger is completed, goodwill is included in the financial statements of the listed company. According to the statistics of Chinese Stock Market Accounting Research (CSMAR) database, the proportion of companies with goodwill recognition (GR) on the balance sheet date in China's listed companies has increased from $28.72 \%$ in 2007 to $55.02 \%$ in 2019, and the net goodwill had also increased from 37.629 billion yuan (5.141 billion dollars, according to the exchange rate in the end of 2007) in 2007 to 1306.963 billion yuan (202.238 billion dollars, according to the exchange rate in the end of 2019) in 2019. It can be seen that the scale of companies with GR and the scale of goodwill among listed companies has increased rapidly year by year. If the GR brings stock price fluctuations of the company, it will affect the stability of the entire capital market directly. GR from corporate M\&A is closely related to the performance of listed companies, and it is usually seen as having a positive influence on firm value [1]. According to the theory of merger efficiency, M\&A generate merger goodwill, increase synergies, and improve company's value [2]. As the insider of the company, the shareholders have private information concerned of future value of the firm. They have positive expectations on the firm's future value. Consequently, they would increase their holdings after GR in order to max their wealth.

After the listed company recognized goodwill, along with the company's production and operation activities, the value of the goodwill gradually shifts. When the future economic benefits of the acquired asset for the merger of the listed company are far lower than its book value that is included in the financial statements, goodwill is impaired. Goodwill impairment (GI) is seen as a negative message to the stock market. In January 2020, Zhongsheng Pharmaceutical hit the lower price limit at the same day after announcing a GI of 
740 to 780 million yuan (114.022 to 120.185 million dollars, according to the exchange rate in January 2020). In January 2020, Global Info Tech's stock price dropped $10.15 \%$ after announcing a GI of 645 million to 794 million. There is a prevailing issue that stock prices dive soon after GI. As the owners of firms, block shareholders have a great intention to stabilize the stock price to prevent fire sale because of investors' scared sentiment. Fire sale would induce stock price plunging and dry-up of liquidity. Thus, stabilizing stock price would keep the market value of firm in a reasonable level, and it also avoids stock price crash. Hence, block shareholders will increase their holdings. A great deal of longing prevents the stock prices' dropping persistently; meanwhile, shareholders' longing is a positive signal in stock markets, which can allay panic of external investors. In general, block shareholders would increase their position to stabilize the stock price soon after GI.

To stay in step with International Financial Reporting Standards (IFRS), Chinese Accounting Standards for Business and Enterprises (ASBE) set the rules of GR in 2006 as follows. After GR, firms must test whether they should make goodwill impairment in a regular base. When the target firm of M\&A would bring down the value of the original firm, they need to make goodwill impairment and adjust the book value in time. Goodwill impairment brings negative expectation in regard to firm's value. Additionally, the slow growth rate of the Chinese economy and the depression of the world economy deepen the negative expectation of GI. Along with the rapid growth of GR due to large amount of M\&A, the risk of GI might bring severe economic blow.

To cope with the underlying risk of GI, Chinese Security Regulatory Commission (CSRC) issued "No.8 Tips of Accounting Supervision Risk, Goodwill Impairment" in November 2018. It requires related department need to strengthen the supervision of GI. CASC (China Accounting Standards Committee) issued "Feedback from the Advisory Committee Members on Some Issue Documents of Accounting Standards Advisory Papers" in January 2019, and it recommended goodwill amortization. But goodwill amortization is not adopted for the following reason. If goodwill increases on regular basis in the future, amortization would damage the authenticity. Meanwhile, IFRS also considered goodwill amortization. However, there is no evidence showing that amortization is a suitable way to improve the quality of financial reports. Hence, International Accounting Standards Board released "Business Combinations-Disclosures, Goodwill and Impairment," which suggested carrying out impairment of goodwill instead of amortization. Hence, ASBE might retain the current method of impairment according to IFRS.

GI might be a warning of increasing risk of firms in the future, which means a negative expectation of future growth. As an insider of the company, block shareholders have a more accurate judgment on the company's intrinsic value and performance prospects. Block shareholder transactions contain more judgments about the economic situation and future trends [3], and their transactions are informative [4-6]. Shareholder transaction decisions will have a significant impact on the market. Therefore, we first study the reaction of block shareholders after GR according to the data from 2007 to 2019 in the Chinese stock market. GR and GI send different messages to external investors, as GR is a positive signal while GI is a negative signal. Although, theoretically speaking, both GR and GI cause increasing position of block shareholders, they have different mechanisms. GR appears in M\&A, and M\&A usually drives stock prices up [2]. Hence, block shareholders increase their position to max their private wealth. However, GI is a signal of declining of future firm revenue, and it drives stock price down. Hence, block shareholders increase their position to stabilize stock price according to signal theory [7]. After we establish the relation between GR and block shareholder's behaviour as well as GI and shareholder's behaviour, respectively, we shift our focus on influence of firms' characteristics to this very relation. We study the difference between privately owned firms and state-owned firms. The large number of state-owned firms is an issue with the Chinese characteristics. The first shareholders of state-owned firms are standing for the country, and these shareholders value political perspective much more than private wealth, and there is a difference between shareholders' behaviours of state-owned firms and privately owned firms, respectively [8]. Therefore, facing GI and GR, state-owned firms' block shareholders might react differently with privately owned firms' block shareholders. We focus on the difference via subsample panel data regression.

The rest of this paper is organized as follows: Section 2 presents the hypothesis of this research. Section 3 discusses the research methodology. Section 4 presents the main empirical results. Section 5 presents the difference between privately owned firms and state-owned firms. Section 6 draws the conclusions.

\section{Hypothesis}

2.1. The Impact of GR on the Increasing Holdings of Block Shareholders. Different scholars have different research conclusions on the relationship of goodwill and company value. One view is that with the GR from M\&A, the company's stock price will gradually rise. Goodwill has a positive impact on company profitability and market value [9]; goodwill can increase the company's stock price significantly $[10,11]$. Another view is that with GR brought about by M\&A, the company's stock price will decline day by day. Firstly, the company may only consider short-term performance without long-term vision and fail to evaluate the acquired company properly. As a result, the company may recognize goodwill blindly leading to merger premiums and overestimation of goodwill; secondly, when goodwill is overestimated, if the company's resources cannot be effectively integrated after the merger, which will further increase the financial burden of the acquirer, so it will reduce the company's value. Therefore, the goodwill of listed companies will affect company value adversely [12]. Huang and Tang [13], Wei and Zhu [14], and Zheng et al. [15] found that high 
goodwill will reduce the company's future performance significantly.

As a product of a company's premium M\&A, goodwill is the potential economic value of the merged party's future excess returns to the merging party [16]. According to the theory of M\&A efficiency, as well as the concept of excess returns, M\&A can change the efficiency of both parties, generate synergy effects, achieve complementation of resources, and bring future expected excess returns to the company, thereby enhancing the company's value $[1,2]$. In addition, goodwill also reflects the acquirer's recognition of the acquired company's value, which can be used as a positive signal. At the same time, block shareholders, as the company's insiders, have a better understanding of the company's internal realities and information. If block shareholders are optimistic about the company's business prospects, they are more willing to increase their holdings to release internal good information that they are optimistic about the company's future development trend to the outside world. And the behaviour of the increasing holdings of block shareholders can also be used as a positive signal to attract more external investors and increase personal income. According to the M\&A arbitrage concept, due to the price of the M\&A has difference, when the stock price of the acquirer relative to the acquired party is overvalued, the insiders of the companies of both parties may carry out arbitrage behaviours and obtain excess returns $[17,18]$. In other words, when M\&A activities generate goodwill, insiders will use their own information advantages to obtain immediate benefits by increasing the shareholdings [19].

Due to the existence of certain "economic rationality," whether it is the extensional development brought about by large-scale M\&A or the high-quality development brought about by value mergers, it is expected that they will bring excess returns to the company. Therefore, with the GR brought about by M\&A, the stock price rises accordingly [10]. Insiders are more optimistic about the company's future development trend, and block shareholders choose to increase their shareholding accordingly. According to the explanation of signal transmission motivation [20], compared with external investors with a lack of information, as insiders of the company, block shareholders have unique information advantages and understand the company's operating conditions and development prospects fully, in order to promote the company's development and enhance their own interests, block shareholders usually adopt the behaviour of increasing holdings to send positive signals to external investors and show their recognition of the good prospects in the future. Therefore, if the company's M\&A activity generates GR during the current period, block shareholders are more inclined to increase their shareholdings. Based on the discussion above, we formulate the following hypothesis:

Hypothesis 1. Compared with companies without GR, block shareholders of companies with GR are more inclined to increase their shareholdings.

Hypothesis 2. Compared with companies with less GR, block shareholders of more GR companies in the current period are more inclined to increase stock holdings.

2.2. The Impact of GI on the Increasing Holdings of Block Shareholders. Scholars hold different views on the research between GI and company value fluctuations. One view is that GI, as a potential crisis derived from the goodwill of company's M\&A, is regarded by investors as a signal of declining in the company's stock price [21], which has an adverse effect in the company's future development. GI has been shown to be negatively correlated with stock market performance [22]. The lower the stock price, the more GI is accrued [23]. Lu and Sun [24] and Lin and Yang [25] found that GI will reduce the company's financing ability, the company's stock price, and the stock return rate and destroy the company's value. Therefore, GI can be used as an intuitive economic reflection of the deterioration of the economic environment, the downturn in the stock market, and the crisis of corporate performance [26].

Due to the limited ability of external investors to obtain the company's internal information, when they learn that the company's goodwill has been impaired, they will have a negative psychology, to reduce their expectations on the stock price, and have an adverse impact on the company [27]. Another view is that the company's provision of GI will not have an adverse effect on the stock price. On the one hand, the company may have problems with resource integration in the short term after the merger, GI caused by the failure of M\&A to achieve the promised performance has become more common, and the degree of market response has become flat. On the other hand, the company may conduct earnings management for the provision of GI, the company's information is relatively low in truthfulness [23]. Additionally, the GI test has a certain degree of subjectivity; therefore, external investors may have doubts about GI by the company's disclosed, and they do not believe that GI can reflect the company's financial status and future development prospects truly $[28,29]$, so the provision of GI may not cause a decline in stock prices.

The essence of GI is the economic loss caused by the acquirer's failure to complete the promised performance in high-value M\&A. Therefore, the company's behaviour of accruing goodwill impairment may reduce the company's value to a certain extent. At this time, as the company's insiders, block shareholders have a better understanding of the company's true financial capabilities and future development due to information asymmetry with external investors. Based on the needs of company development and personal interests, they are more inclined to use the potential information advantage of symmetry and cover up the unfavourable news for the company's development and personal interests $[30,31]$ so as to mitigate the negative impact of GI on the company. Besides, adopting increasing holdings conveys the company's "good" signal to the outside world so as to affect the judgment of external investors from stabilizing investor confidence. Accordingly, the "good" signal may inspire external investors chasing behaviour, which is helpful of maintaining the company smooth 
operation [32]. Therefore, GI of the company is related to the increasing holdings of block shareholders closely.

According to the signalling motivation [20], if the company's provision of GI is less, as an insider, the block shareholder has a better understanding of the company's situation and may have the information that the postmerger company's development is good. In order to further increase the stock price and obtain personal income, block shareholders may choose to increase their shareholdings to send signals to the outside world, implying that the company is operating well and has a bright future. Therefore, the behaviour of the increasing holdings of block shareholders is regarded by external investors as a good performance of the company's future development. However, since less GI has a lesser impact on the company, the tendency of the increasing holdings of block shareholders is not obvious. When there are more provisions for GI, the stock market is sluggish, the stock price is undervalued [33], and the company is even facing risks. In order to help the company overcome difficulties and maintain stable operations, the company's block shareholders usually choose to increase stock holdings to save the company and stabilize market confidence [34]. Simultaneously, perhaps the company has a "big bath" surplus behaviour, and block shareholders still maintain the company's future development. External investors generally recognize that the behavior of increasing the holdings of major shareholders is of signal significance, so major shareholders are more motivated to signal to the outside world that they still have expectations of the company, accordingly individuals can gain benefits while attracting more investors to the company.

Due to the price difference of M\&A activities, when the stock price of the acquiring party relative to the acquired party is overvalued, the insiders of the companies of both parties may carry out arbitrage behaviours on this M\&A transaction so as to obtain excess returns in the future. Behaviour of M\&A arbitrage can obtain excess returns based on the cash acquisitions in the US market from 1971 to 1985 [35]. Goodwill is a manifestation of the value of excess income obtained by the acquirer, and the amount of goodwill means the size of the arbitrage opportunities. When the goodwill is recognized in the current period of M\&A activities, the more goodwill is recognized in the current period of the merger, the greater the price difference of this merger is, and insiders will use their own information advantages to increase the proportion of shareholdings to ensure personal income. That is, the larger the scale of goodwill, the stronger the motivation of block shareholders to increase their holdings for arbitrage. Therefore, we formulate the following hypothesis.

GI is a potential crisis derived from the goodwill of a company's M\&A [36], which means that the company's future development trend is poor, and it is often regarded by investors as a signal of the company's share price decline. Thus, impairment is negatively correlated with stock market performance [37]. At the same time, the provision of GI indicates that the company's forecast of future performance is declining, which may have a further attack to the stock price. Therefore, as an intuitive economic reflection of the company's performance decline, GI may have an adverse impact on the company [27]. Once the GI provision occurs, the stock price is more likely to fall. GR and the scale of GR may make block shareholders more inclined to increase stock holdings; when the value of goodwill is depressed with the company's business activities and GI is accrued, if the degree of GI is different, it may also have different effects on the tendency of the increasing holdings of block shareholders.

For companies with a low degree of GI, the financial status is relatively good [26], the impact of GI on the company's stock price is limited, and block shareholders do not need to use a signalling mechanism to stabilize the market. At this time, the motivation to increase shareholdings is small. Moreover, the appropriate disclosure of GI helps the market recognize that companies have made relatively sufficient disclosures of financial information and performance expectations, and financial statement data can more truly reflect the company's financial and operating conditions. Although GI means that it may take some time for the company's performance to recover, there are still good expectations for the future. Therefore, when the company's GI provision ratio is low, the tendency of the increasing holdings of block shareholders is limited.

For samples with a high degree of GI, the tendency of the increasing holdings of block shareholders may be more pronounced. When the degree of GI is high, poor performance expectations will lead to more negative information about the company. If a large amount of negative information flows into the market, it may cause a stock price collapse [38]. Under the premise of information asymmetry, management is more inclined to hide negative news in order to pursue its own interests [39]; block shareholders will choose to increase their stock holdings supporting management, which passes on the "good" signal to the outside world to boost investor expectations [40] and stabilize market confidence. External investors recognize generally that the behaviour of the increasing holdings of block shareholders has signal significance, and that stable shareholding can obtain significant and positive excess returns and increase confidence for the company's future development [41]. Therefore, with the more GI recognized by the company, the greater the tendency of block shareholders to increase their holdings. In summary, we formulate the following hypothesis:

Hypothesis 3. The more GI accrued in the current period, the stronger the tendency of the increasing holdings of block shareholders.

\section{Methods}

3.1. Sample and Data Sources. The data used in this study consists of China's A-share nonfinancial listed companies from 2007 to 2020. In order to make the data more effective, during the sample selection process, the following screenings were performed: (1) excluding data with GR or GI reserves being 0 at the same time; (2) excluding block shareholders increasing holdings/total shares smaller than $0.01 \%$; (3) excluding enterprises listed in 2017 and after; (4) excluding companies with missing data on major variables; and (5) 
excluding data in 2020. The outbreak of COVID-19 in 2020 will have a severe impact on the Chinese stock market, which will affect the scale of GR and the scale of GI; the relationship between the decision of block shareholders and GR and GI may be more affected by COVID-19. To control the influence of extreme values, all continuous variables in the sample data are processed with winsorize (1\%-99\%). A total of 12,888 observations from 2073 companies were obtained. The data in this paper are derived from the WIND database, the CHOICE database, and the CSMAR database; and the study uses EXCEL and STATA13.0 to collate the data and perform statistical analysis.

\subsection{Variables and Models}

3.2.1. Variables. The dependent variable is SI (SI is the tendency of the increasing holdings of block shareholders). SI refers to the tendency of the increasing holdings of block shareholders. The block shareholders include the investors holding more than $5 \%$ of the shares or the top ten shareholders of a listed company, who will take the decision of continuing to purchase the company's shares through the secondary stock market according to the information advantage. In particular, although the block shareholder is an insider, the transaction behaviour of the block shareholder's increase in holdings is not consistent with insider trading. Insider trading may be illegal or legal. Illegal insider trading focuses more on the use of major events that affect stock prices that are unknown in advance for trading, and the trading purpose is for obtaining short-term excess returns. The legal insider trading focuses more on the company's intrinsic value and future performance, and the trading purpose is to obtain long-term excess returns. Because strong regulatory systems can significantly limit the risks of insiders using undisclosed information [42], and insider trading has significant long-term excess return effect [43], the trading decision of increasing their shareholding basically complies with the regulatory framework. In order to test the influence of GR and GI on SI, this paper represents SI from two aspects. Firstly, the virtual variable that is whether block shareholders increase their holdings (SIV) is taken as the first-aspect dependent variable, which reflects whether the holdings' proportion of block shareholders has been increased. The virtual variable explores the logical relationship between GR and SI; GI and SI initially. Secondly, in order to analyse the quantitative relationship specifically between GR and SI; GI and SI, the quantitative indicators of SI are taken as the second aspect of dependent variables. Based on the research of Li et al. [38], the changes of the increasing holdings of block shareholders (SIQ); that is, the cumulative number of changes in holdings of block shareholders in the current period/total shares is selected as the dependent variable in this paper. SIQ reflects SI from the angle of quantity. The larger the index, the stronger the SI.

The independent variables are GR and GI. GR is expressed in two aspects: whether to recognize goodwill (GRV) and the degree of goodwill recognition (GRQ). Among them, GRV is a dummy variable, used to verify the logical relationship between GRV and SIV. Based on the research of scholars such as Li et al. [38] and Deng and Mei [44], the added goodwill in this period/total assets (GRQ) is used as independent variables to reflect the scale of GR brought by corporate M\&A, used to verify the logical relationship between GRQ and SIQ.

At the same time, according to the research of $\mathrm{Hu}$ and $\mathrm{Li}$ and other scholars [45], this paper takes the provision for goodwill impairment in the current period/total assets (GIQ) as an independent variable to reflect the scale of GI by enterprises in the current period; these quantitative indicators analyse the relationship between GIQ and SIQ concretely.

GR and GI impact on SI, which is bound to be affected by the enterprise characteristics and the financial situation. For example, the scale of the enterprise (ES) affects the corporate development, which in turn affects SI [46, 47]; the net cash flow generated from operating activities/total shares (OC) can reflect the ability of generating cash flow out of capital. The stronger OC is, the greater SI is [48]; the size of the board of supervisors (BS) (in Chinese corporations, board of supervisors is a department that supervises the daily operation of firms on behalf of stakeholders. Board of supervisors is set to avoid abusing power of managers and block shareholders) measures the effect of company internal governance $[49,50]$, providing positive information for the increasing holdings of block shareholders; the lower the price-to-book ratio (PB), the lower the risk [51], and the investment value becomes higher; the long-term capital debt ratio (LCD) reflects the company's long-term capital structure [52] and also affects the holdings scale of the block shareholders; the cost and charge margin (CCM) can measure the agency costs between managers and shareholders: the better the performance of managers, the higher the SI [53]. Therefore, as previously mentioned, this paper takes ES, OC, BS, PB, LCD, and CCM as control variables. And year and industry are introduced as control variables. The definitions of variables are shown in Table 1 .

3.2.2. Models. The following regressions model are established to verify the above assumptions.

Model 1. It tests hypothesis 1 , which verifies the relationship between GRV and SIV:

$$
\mathrm{SIV}=a_{0}+a_{1} \times \mathrm{GRV}+\sum\left(\alpha_{i} \times X_{i}\right)+\varepsilon
$$

Model 2. It tests hypothesis 2 , which verifies the relationship between GRQ and SIQ:

$$
\mathrm{SIQ}=a_{0}+a_{1} \times \mathrm{GRQ}+\sum\left(\alpha_{i} \times X_{i}\right)+\varepsilon .
$$

Model 3. It tests the hypothesis 3, which verifies the relationship between GIQ and SIQ:

$$
\mathrm{SIQ}=a_{0}+a_{1} \times \mathrm{GIQ}+\sum\left(\alpha_{i} \times X_{i}\right)+\varepsilon .
$$

Among them, $a_{0}$ represents the constant, $a_{1}$ represents the coefficient of the independent variables, $\alpha_{i}$ represents the coefficient of the control variables, $X_{i}$ represents the control variables, $\varepsilon$ represents the random error term, and the meaning of the rest of variables is shown in Table 1 . 
TABLE 1: Variable definitions.

\begin{tabular}{|c|c|c|c|}
\hline $\begin{array}{l}\text { Variable } \\
\text { dimension }\end{array}$ & Variable name & Proxy & Definition \\
\hline \multirow{2}{*}{$\begin{array}{l}\text { Dependent } \\
\text { variables }\end{array}$} & $\begin{array}{l}\text { Whether block shareholders } \\
\text { increase their holdings }\end{array}$ & SIV & $\begin{array}{l}\text { Increased holdings in the current period, recorded as } 1 \text {; without increased } \\
\text { holdings in the current period, recorded as } 0\end{array}$ \\
\hline & $\begin{array}{l}\text { The changes of the increasing } \\
\text { holdings of block shareholders }\end{array}$ & SIQ & $\begin{array}{l}\text { The cumulative number of changes in holdings of block shareholders in the } \\
\text { current period/total shares }\end{array}$ \\
\hline \multirow{3}{*}{$\begin{array}{l}\text { Independent } \\
\text { variables }\end{array}$} & & GRV & $\begin{array}{c}\text { Added goodwill in this period is recorded as } 1 \text {; without added goodwill in } \\
\text { this period is recorded as } 0\end{array}$ \\
\hline & Degree of goodwill recognition & GRQ & The added goodwill in this period/total assets \\
\hline & Degree of goodwill impairment & GIQ & Provision for goodwill impairment in the current period/total assets \\
\hline \multirow{8}{*}{ Control variables } & Enterprise size & ES & LN (total assets) \\
\hline & Operating cash flow & OC & The net cash flow from operating activities/total shares \\
\hline & Board of supervisors & BS & The number of supervisory board \\
\hline & $\mathrm{P} / \mathrm{B}$ ratio & $\mathrm{PB}$ & $\begin{array}{l}\text { Current value of the closing price of the current period/(total value of } \\
\text { owner's equity in the end of this period/the value of paid-in capital for the } \\
\text { end of current period) }\end{array}$ \\
\hline & Long-term capital debt ratio & LCD & $\begin{array}{c}\text { Total noncurrent liabilities/(total owner's equity + total noncurrent } \\
\text { liabilities) }\end{array}$ \\
\hline & Cost and charge margin & $\mathrm{CCM}$ & $\begin{array}{c}\text { Total profit/(operating costs }+ \text { sales expenses }+ \text { management } \\
\text { expenses }+ \text { financial expenses })\end{array}$ \\
\hline & Years & Year & $\begin{array}{l}\text { Annual dummy variable. When the company is in the year, take } 1 \text {; } \\
\text { otherwise, take } 0\end{array}$ \\
\hline & Industry & Ind & $\begin{array}{l}\text { Industry dummy variables. When the company is in this very industry, } \\
\text { take } 1 \text {; otherwise, take } 0\end{array}$ \\
\hline
\end{tabular}

\section{Results}

4.1. Descriptive Statistics and Correlation Analyses. Table 2 shows descriptive statistics like the mean, minimum, median, maximum, and standard deviation of each statistical indicator. The mean of SIV is 0.2419 , which is greater than the median of 0 , and the standard deviation is 0.4282 , indicating that SIV has a skewed distribution and a large degree of dispersion. SIQ presents the same characteristics. The mean of GRV is 0.2037 , which is greater than the median of 0 , indicating that the distribution of goodwill is biased. Moreover, the maximum of GRQ is 0.2866 , and the mean is 0.0115 . This further shows that from the overall sample of GR, the degree of GR caused by M\&A of some companies is relatively high, and the level of goodwill is relatively close, and the smaller companies also account for a certain size in the overall sample. The distribution of the degree of GIQ is biased, indicating that some companies have accrued a large amount of GI, which affects the company's operating performance. In summary, it can be seen that in the overall sample, GR is common relatively, and a considerable number of companies recognized goodwill on a large scale, and GI caused by GR should not be underestimated. Compared with the biased and discrete degree of the company's GR and provision of GI, the increasing holdings of block shareholders also have similar characteristics. After the company recognized the goodwill, the adjustment effect of the provision of GI on SI is also complicated. The following will verify the correlation between GR and SI; GI and SI.

The Pearson correlation results are presented in Table 3, as well as the results of the significance test performed to detect whether there is collinearity between the variables in the table. In the total sample, GRV and GIQ; GRQ and GIQ are significantly positively correlated; it can be seen that for the company with an increase in GR, it may also increase the degree of GI. This means that if the company recognized goodwill during the merger, there is a possibility of subsequent impairment, and the greater the GR, the larger subsequent calculation of the scale of GI. Therefore, companies that recognized high amounts of goodwill will have the risk of "explosion" of goodwill. GRV and SIV are correlated positively and significantly, indicating that if the company recognized goodwill, block shareholders might be more inclined to increase stock holdings. GRQ and SIQ are correlated positively and significantly, indicating that as the scale of the company's recognized goodwill increases, SI may gradually increase. The above results verify the research hypotheses 1 and 2 preliminarily. GIQ is correlated significantly and negatively with SIQ, indicating that the larger the company's provision for GI, the more SI may decrease. Hypothesis 3 has not been verified yet, but since other influencing factors of the dependent variable are not controlled at this time, further regression analysis is still needed. The correlation coefficients among other variables are also reasonable. The correlation coefficients among most control variables are not high; however, they are correlated significantly. A few control variables have correlation coefficient values higher than 0.3 , so all variables are tested by VIF. The result shows that the highest VIF is 2.05 , and the rest are between 1 and 2, indicating that the collinearity is not serious, the variable definitions are more reasonable, and the regression results are more credible. 
TABle 2: Descriptive statistics.

\begin{tabular}{|c|c|c|c|c|c|c|}
\hline Variables & $N$ & Mean & Minimum & Median & Maximum & Std. deviation \\
\hline SIV & 12888 & 0.2419 & 0 & 0 & 1 & 0.4282 \\
\hline SIQ & 12888 & 0.0105 & 0 & 0 & 0.2060 & 0.0308 \\
\hline GRV & 12888 & 0.2037 & 0 & 0 & 1 & 0.4027 \\
\hline GRQ & 12888 & 0.0115 & 0 & 0 & 0.2866 & 0.0435 \\
\hline GIQ & 12888 & 0.0017 & 0 & 0 & 0.0795 & 0.0093 \\
\hline ES & 12888 & 22.3207 & 19.9415 & 22.1355 & 26.2981 & 1.2846 \\
\hline $\mathrm{OC}$ & 12888 & 0.4009 & -2.1470 & 0.2970 & 3.5683 & 0.8005 \\
\hline BS & 12888 & 3.5674 & 2 & 3 & 7 & 1.0475 \\
\hline $\mathrm{PB}$ & 12888 & 3.4699 & 0 & 2.7054 & 15.8395 & 2.7545 \\
\hline LCD & 12888 & 0.1498 & 0 & 0.0833 & 0.7054 & 0.1674 \\
\hline CCM & 12888 & 0.1307 & -0.5617 & 0.0991 & 0.9162 & 0.1905 \\
\hline
\end{tabular}

TABLE 3: Correlation analysis.

\begin{tabular}{|c|c|c|c|c|c|c|c|c|c|c|c|}
\hline & SIV & SIQ & GRV & GRQ & GIQ & ES & OC & BS & PB & LCD & CCM \\
\hline SIV & 1 & & & & & & & & & & \\
\hline SIQ & $0.6040^{* * *}$ & 1 & & & & & & & & & \\
\hline GRV & $0.0401^{* * *}$ & $0.0200^{* *}$ & 1 & & & & & & & & \\
\hline GRQ & $0.0681^{* * *}$ & $0.0570^{* * *}$ & $0.5206^{* * *}$ & 1 & & & & & & & \\
\hline GIQ & -0.0112 & $-0.0209^{* *}$ & $0.0575^{* * *}$ & $0.0319^{* * *}$ & 1 & & & & & & \\
\hline ES & $0.0662^{* * *}$ & $0.0851^{* * *}$ & $0.0623^{* * *}$ & $-0.0606^{* * *}$ & $-0.0470^{* * *}$ & 1 & & & & & \\
\hline OC & $0.0521^{* * *}$ & $0.0276^{* * *}$ & $-0.0235^{* * *}$ & $-0.0331^{* * *}$ & $-0.0526^{* * *}$ & $0.2271^{* * *}$ & 1 & & & & \\
\hline BS & -0.0067 & $0.0158^{*}$ & $-0.1033^{* * *}$ & $-0.0971^{* * *}$ & $-0.0611^{* * *}$ & $0.2671^{* * *}$ & $0.1177^{* * *}$ & 1 & & & \\
\hline $\mathrm{PB}$ & $0.0246^{* * *}$ & -0.0084 & 0.0090 & $0.0558^{* * *}$ & $-0.0158^{*}$ & $-0.3645^{* * *}$ & $-0.0324^{* * *}$ & $-0.1004^{* * *}$ & 1 & & \\
\hline LCD & 0.0143 & $0.0479^{* * *}$ & $-0.0227^{* * *}$ & $-0.0731^{* * *}$ & $-0.0258^{* * *}$ & $0.5551^{* * *}$ & $0.0645^{* * *}$ & $0.2061^{* * *}$ & $-0.1527^{* * *}$ & 1 & \\
\hline $\mathrm{CCM}$ & 0.0055 & -0.0100 & $0.0303^{* * *}$ & $0.0578^{* * *}$ & $-0.2869^{* * *}$ & $-0.0255^{* * *}$ & $0.1248^{* * *}$ & $-0.0178^{* *}$ & $0.1089^{* * *}$ & $-0.1270^{* * *}$ & 1 \\
\hline
\end{tabular}

Note. ${ }^{* * *} p<0.01,{ }^{* *} p<0.05$, and ${ }^{*} p<0.1$.

\subsection{Hypothesis Tests}

4.2.1. Regression Results of Hypothesis 1. Table 4 is the empirical results of Model 1. Columns (1) and (2) in the table show the relationship between GRV and SIV. Column (1) shows that the coefficient of GRV is positive and significant at the $1 \%$ level when the control variables are not considered; column (2) shows that the coefficient of GRV is significant and positive at the $5 \%$ level when the control variables are considered; the results support Hypothesis 1. According to the above empirical results, if goodwill is recognized in the current period, block shareholders of companies with GR are more inclined to increase their shareholdings.

4.2.2. Regression Results of Hypothesis 2. Columns (1) and (2) in Table 5 show the impact of GRQ on SIQ. Excluding the data that without GR in the current period, there are 2625 observations in the sample of GR in the current period. Column (1) shows that the coefficients of GRQ and SIQ are significant and positive at the $1 \%$ level when the control variables are not considered; column (2) shows that the coefficients of GRQ and SIQ are still significant and positive at the $1 \%$ level when the control variables are considered, which supports Hypothesis 2. According to the above empirical results, the more GR of the company in the current period, the stronger the SI.

The empirical results of Model 1 and Model 2 show that the goodwill will stimulate block shareholders to increase
TABLE 4: Regression results of Hypothesis 1.

\begin{tabular}{lcc}
\hline \multirow{2}{*}{ Variables } & \multicolumn{2}{c}{ Model 1} \\
& $(1)$ SIV & $(2)$ SIV \\
\hline GRV & $0.0312^{* *}(0.011)$ & $0.0249^{* *}(0.043)$ \\
ES & & $0.0684^{* * *}(0.000)$ \\
OC & $0.0060(0.338)$ \\
BS & & $-0.0126(0.272)$ \\
PB & & $0.0132^{* * *}(0.000)$ \\
LCD & & $-0.2855^{* * *}(0.000)$ \\
CCM & $0.2217(0.122)$ & $0.0574^{*}(0.054)$ \\
Constant & Included & Included \\
Year and industry & $128884^{* * *}(0.000)$ \\
Observations & 0.0169 & 12888 \\
$R$-squared & & 0.0252 \\
\hline
\end{tabular}

Note. $p$ statistics are in parentheses. ${ }^{* * *} p<0.01,{ }^{* *} p<0.05$, and ${ }^{*} p<0.1$.

their holdings; and during the accounting period for recognizing goodwill, the company will allocate and redistribute related resources after the merger. When a company's resources can be used in related businesses at low cost during allocation and redistribution activities, the synergies based on M\&A come into play, and the company's development prospects may be better. Among the samples which recognized goodwill in the current period, the synergies brought about by M\&A will more significantly encourage block shareholders to tend to increase their shareholdings. When the company recognized goodwill, the 
TABLE 5: Regression results of Hypothesis 2.

\begin{tabular}{lcc}
\hline \multirow{2}{*}{ Variables } & \multicolumn{2}{c}{ Model 2} \\
\hline GRQ & $0.0559^{* * *}(0.000)$ & $0.0550^{* * *}(0.000)$ \\
ES & & $0.0053(0.301)$ \\
OC & $-0.0026(0.118)$ \\
BS & & $-0.0040(0.315)$ \\
PB & & $0.0004(0.387)$ \\
LCD & & $-0.0438^{* * *}(0.005)$ \\
CCM & & $-0.0005(0.937)$ \\
Constant & $-0.0469^{* *}(0.013)$ & $-0.1501(0.200)$ \\
Year\&industry & Included & Included \\
Observations & 2625 & 2625 \\
$R$-squared & 0.0500 & 0.0638 \\
\hline
\end{tabular}

Notes. $p$ statistics are in parentheses. ${ }^{* * *} p<0.01,{ }^{* *} p<0.05$, and ${ }^{*} p<0.1$.

higher GRQ means the higher the M\&A premium, the greater the space for future investment returns, and the stronger the SI.

4.2.3. Regression Results of Hypothesis 3. As a signal that investors believe that the company's stock price will fall, GI may have a further impact on the company's stock price. Based on the company's stable development and personal long-term income, block shareholders are usually more inclined to choose to increase their shareholdings to send positive signals to the outside. Taking into account the above correlation analysis results, GI and SI show a negative correlation. This paper further verifies the moderating effect of different degrees of GI on SI after the company recognizes the goodwill. Since GRQ and GIQ are continuous variables, this paper will group the samples of companies that have accrued GI according to the degree of impairment to verify the moderating effect. Taking GIQ as the measurement standard, there are a total of 1820 data. Referring to Brogaard et al. [54], the samples are evenly divided into three groups; grouping results is 607,607 , and 606 pieces of data from low to high. Table 6 shows the empirical results of Model 3. Among the samples with high degree of GI in the current period, GIQ and SIQ are significant and positive.

According to the empirical results in Table 6, in the samples with low degree of GI and medium degree of GI, the correlation between the two is not significant. This paper believes that the reason for this result is that when GI is small, the impact on the performance of the stock in the secondary market is limited, so block shareholders do not need to send signals to stabilize the stock price by increasing their holdings. Only when the company accrues large-scale GI, the investor's strength reflects the risk of stock price decline or stock price collapse, thereby affecting the decision of block shareholders to increase their holdings. The empirical result supports Hypothesis 3, indicating that the higher the degree of impairment, the more significant the impact of the degree of GR on SI.

\subsubsection{Robustness Tests}

(1) Substitution Variable Method. The increasing holdings of block shareholders have the role of a weather vane, which has an important impact on the fluctuation of the stock market. Among the shareholders who hold more than $5 \%$ of the shares or rank in the top ten, the shareholders who hold more shares are generally more stable and will not be easily replaced. Moreover, shareholders with more shares have more opportunities to participate in the company's business decision-making and may respond to goodwill risks more promptly, which plays a decisive role in smoothing the company's goodwill risks and stabilizing market expectations. Thus, in order to test the robustness of the research results, we use the new dependent variable $\mathrm{SIV}^{*}$. (SIV ${ }^{*}$ is whether top three shareholders increase their holdings.) Also, we use SIQ* $^{*}$ (SIQ* is the cumulative number of changes in holdings of the top three shareholders in the current period/total shares.) to replace SIQ. Regression analysis is performed using Models 1-3, and almost all the results in Table 7 are still significant.

(2) Instrumental Variable Method. This paper adopts the panel data instrumental variable method to solve the influence of missing variables on the research results. GI mainly comes from the size of the asset premium brought about by M\&A. The higher the performance commitment is set during M\&A, the higher the asset premium becomes, also the higher the degree of GI would generate in the future. This paper uses the performance commitment multiple, that is, the performance commitment in the current period/ total assets as the instrumental variable. Firstly, a one-stage regression is carried out on the degree of GI and the performance commitment multiple in the same period. The regression results show that they are correlated significantly. Then, a two-stage regression is performed on the performance commitment multiple and SIQ. The regression coefficient is still significant and positive, indicating that the main hypothesis of GIQ and SIQ is still valid after controlling the endogenous problem (Table 8).

(3) Sample Grouping Method. Taking into account the result that GI is negatively related to SI in the above correlation analysis results, it may be that the samples with lower impairments partly cover the results of the samples with higher impairments. After the degree is divided into three equal parts in the regression analysis, GI of the high-impairment group is correlated positively with the increasing holdings of block shareholders, indicating that the different degree of impairment of listed companies will have the different adjustment mechanism on SI, and there is typical trend characteristics in high-impairment group. The more GI is accrued, the stronger the SI. Thus, in order 
TABLE 6: Regression results of Hypothesis 3.

\begin{tabular}{lccc}
\hline Variables & & Model 3 & \\
& Low impairment & Medium impairment & High impairment \\
\hline GIQ & $7.8020(0.438)$ & $2.0522(0.494)$ & $0.0288^{*}(0.051)$ \\
ES & $-0.0098(0.509)$ & $0.0142(0.284)$ & $0.0152^{* *}(0.011)$ \\
OC & $-0.0009(0.831)$ & $0.0068(0.105)$ & $0.0079^{* *}(0.047)$ \\
BS & $0.0032(0.369)$ & $0.0324(0.152)$ & $-0.0020(0.691)$ \\
PB & $-0.0034^{*}(0.070)$ & $0.0005(0.633)$ & $0.0009(0.155)$ \\
LCD & $-0.0440(0.260)$ & $0.0456(0.488)$ & $-0.0227(0.220)$ \\
CCM & $-0.0003(0.989)$ & $0.0146(0.534)$ & $-0.0002(0.888)$ \\
Constant & $0.2508(0.444)$ & $-0.4282(0.148)$ & $-0.3195^{* *}(0.014)$ \\
Year and industry & Included & Included & Included \\
Observations & 607 & 607 & 606 \\
$R$-squared & 0.0553 & 0.2183 & 0.1564 \\
\hline
\end{tabular}

Notes. $p$ statistics are in parentheses. ${ }^{* * *} p<0.01,{ }^{* *} p<0.05$, and ${ }^{*} p<0.1$.

TABLE 7: Robustness test: replacing the dependent variable.

\begin{tabular}{|c|c|c|c|c|c|c|}
\hline \multirow{2}{*}{ Variables } & \multicolumn{2}{|c|}{ SIV $^{*}$} & \multicolumn{2}{|c|}{ SIQ* $^{*}$} & \multicolumn{2}{|c|}{ SIQ* $^{*}$} \\
\hline & (1) & $(2)$ & (3) & $(4)$ & $(5)$ & $(6)$ \\
\hline$\overline{\text { GRV }}$ & $0.0333^{* * *}(0.006)$ & $0.0265^{* *}(0.029)$ & & & & \\
\hline GRQ & & & $0.0516^{* * *}(0.000)$ & $0.0509^{* * *}(0.000)$ & & \\
\hline GIQ & & & & & $0.0075(0.569)$ & $0.0261^{*}(0.063)$ \\
\hline ES & & $0.0710^{* * *}(0.000)$ & & $0.0052(0.277)$ & & $0.0125^{* *}(0.022)$ \\
\hline $\mathrm{OC}$ & & $0.0049(0.417)$ & & $-0.0026^{*}(0.097)$ & & $0.0077^{* *}(0.040)$ \\
\hline BS & & $-0.0167(0.112)$ & & $-0.0038(0.330)$ & & $-0.0033(0.476)$ \\
\hline PB & & $0.0124^{* * *}(0.000)$ & & $-0.0003(0.454)$ & & $0.0007(0.224)$ \\
\hline LCD & & $-0.2825^{* * *}(0.000)$ & & $-0.0421^{* * *}(0.006)$ & & $-0.0174(0.301)$ \\
\hline CCM & & $0.0580^{* *}(0.047)$ & & $-0.0018(0.775)$ & & $-0.0004(0.828)$ \\
\hline Constant & $0.2448^{*}(0.093)$ & $-1.2833^{* * *}(0.000)$ & $-0.0239^{* *}(0.032)$ & $-0.1268(0.249)$ & $-0.0038(0.460)$ & $-0.2579^{* *}(0.030)$ \\
\hline Year and industry & Included & Included & Included & Included & Included & Included \\
\hline Observations & 12888 & 12888 & 2625 & 2625 & 606 & 606 \\
\hline$R$-squared & 0.0171 & 0.0254 & 0.0465 & 0.0605 & 0.0802 & 0.1549 \\
\hline
\end{tabular}

Notes. $p$ statistics are in parentheses. ${ }^{* * *} p<0.01,{ }^{* *} p<0.05$, and ${ }^{*} p<0.1$.

TABLE 8: Robustness test: panel instrumental variable regression.

\begin{tabular}{lcc}
\hline \multirow{2}{*}{ Variables } & \multicolumn{2}{c}{ Model 3} \\
& One-stage & Two-stage \\
\hline GIQ & & $0.6852^{*}(0.055)$ \\
Controls & Included & Included \\
Constant & $0.2122^{* * *}(0.000)$ & $-0.4504^{* * *}(0.001)$ \\
Year and industry & Included & Included \\
$R$-squared & 0.2833 & 0.0210 \\
$F$-value & $50.22^{* * *}$ & \\
Wald chi & & $418.70^{* * *}$ \\
Observations & 2280 & 2280 \\
\hline
\end{tabular}

Notes. $p$ statistics are in parentheses. ${ }^{* * *} p<0.01,{ }^{* *} p<0.05$, and ${ }^{*} p<0.1$.

to test the robustness of the research results, the following steps are carried out: regrouping the samples of GI in the current period, reducing the scope of high-impairment groups further, and verifying the adjustment mechanism of the impact of GI on SI. According to GIQ from low to high, first, select 546, 728 , and 546 pieces of data base on the ratio of $30 \%$, $40 \%$, and $30 \%$ in the 1820 group of samples, and then select 728,728 , and 364 pieces of data base on the proportions of $40 \%, 40 \%$, and $20 \%$, respectively, to reduce the range of the high-impairment group gradually, and perform panel fixed-effects regression. According to the regression results, in the low-impairment group and the medium-impairment group of the two classifications, GIQ has a positive or negative impact on SIQ insignificantly, indicating that when the company's provision for GI is low, the scale of GI has not a consistent effect on SI, while in the high-impairment group of the two classifications, there is a significant positive correlation between GIQ and SIQ, and the more rigorous the classification standard of the high-impairment group, the higher the significance between GIQ and SIQ. The results of Hypothesis 3 are verified (Table 9).

\section{State-Owned Firms and Privately Owned Firms}

Studies have found that the nature of the company's property rights will affect the behaviour of the increasing holdings of block shareholders $[8,55]$. The behavioural decisions of block shareholders are inevitably affected by 
TABLE 9: Robustness test: grouping samples.

\begin{tabular}{lcc}
\hline Variables & $(1)$ SIQ & Model 3 \\
& $0.0284^{*}(0.054)$ & $0.0486^{* *}(0.024)$ \\
GIQ & $0.0159^{*}(0.059)$ & $0.0347^{* *}(0.040)$ \\
ES & $0.0107^{* *}(0.032)$ & $0.0216^{* *}(0.029)$ \\
OC & $-0.0021(0.679)$ & $0.0106(0.115)$ \\
BS & $0.0008(0.276)$ & $0.0016(0.275)$ \\
PB & $-0.0200(0.390)$ & $-0.0397(0.436)$ \\
LCD & $-0.0003(0.885)$ & $-0.0007(0.866)$ \\
CCM & $-0.3263^{*}(0.080)$ & $-0.8138^{* *}(0.030)$ \\
Constant & Included & Included \\
Year and industry & 546 & 364 \\
Observations & 0.1294 & 0.3959 \\
$R$-squared & & 365 \\
\hline
\end{tabular}

Notes. $p$ statistics are in parentheses. ${ }^{* * *} p<0.01,{ }^{* *} p<0.05$, and ${ }^{*} p<0.1$.

TABLE 10: State-owned firms versus privately owned firms: the influence of GR.

\begin{tabular}{|c|c|c|c|c|}
\hline \multirow{2}{*}{ Variables } & \multicolumn{2}{|c|}{ State-owned company } & \multicolumn{2}{|c|}{ Privately owned companies } \\
\hline & (1) & (2) & (3) & $(4)$ \\
\hline GRQ & $0.0762(0.231)$ & $0.0647(0.255)$ & $0.0541^{* * *}(0.000)$ & $0.0573^{* * *}(0.000)$ \\
\hline ES & & $0.0429^{* *}(0.020)$ & & $0.0002(0.967)$ \\
\hline $\mathrm{OC}$ & & $-0.0030(0.164)$ & & $-0.0036(0.109)$ \\
\hline BS & & $-0.0019(0.806)$ & & $-0.0011(0.708)$ \\
\hline $\mathrm{PB}$ & & $-0.0006(0.788)$ & & $0.0003(0.558)$ \\
\hline LCD & & $-0.0978^{* *}(0.032)$ & & $-0.0317^{* *}(0.050)$ \\
\hline $\mathrm{CCM}$ & & $-0.0029(0.946)$ & & $0.0006(0.919)$ \\
\hline Constant & $-0.0065(0.647)$ & $-0.9726^{* *}(0.022)$ & $-0.1320^{* * *}(0.000)$ & $\begin{array}{c}-0.1282 \\
(0.286)\end{array}$ \\
\hline Year and industry & Included & Included & Included & Included \\
\hline Observations & 567 & 567 & 2058 & 2058 \\
\hline$R$-squared & 0.0860 & 0.1398 & 0.0716 & 0.0816 \\
\hline
\end{tabular}

Notes. $p$ statistics are in parentheses. ${ }^{* * *} p<0.01,{ }^{* *} p<0.05$, and ${ }^{*} p<0.1$.

TABLE 11: State-owned firms versus privately owned firms: the influence of GI.

\begin{tabular}{|c|c|c|c|c|}
\hline \multirow[t]{2}{*}{ Variables } & \multicolumn{2}{|c|}{ State-owned companies } & \multicolumn{2}{|c|}{$\begin{array}{l}\text { Privately owned companies company } \\
\text { companies }\end{array}$} \\
\hline & (1) & (2) & (3) & (4) \\
\hline$\overline{\text { GIQ }}$ & $-0.0196(0.721)$ & $0.1960(0.376)$ & $0.0067(0.615)$ & $0.0273(0.102)$ \\
\hline ES & & $0.1067^{* *}(0.020)$ & & $0.0132^{* *}(0.028)$ \\
\hline OC & & $0.0090(0.505)$ & & $0.0058(0.140)$ \\
\hline BS & & $-0.0185(0.238)$ & & $0.0019(0.497)$ \\
\hline $\mathrm{PB}$ & & $0.0004(0.174)$ & & $0.0006(0.311)$ \\
\hline LCD & & $-0.1456(0.259)$ & & $-0.0142(0.332)$ \\
\hline $\mathrm{CCM}$ & & $0.0099(0.848)$ & & $0.0004(0.843)$ \\
\hline Constant & $-0.0044(0.623)$ & $-2.3069^{* *}(0.020)$ & $0.0138(0.274)$ & $-0.2872^{* *}(0.031)$ \\
\hline Year\&industry & Included & Included & Included & Included \\
\hline Observations & 83 & 83 & 523 & 523 \\
\hline$R$-squared & 0.1197 & 0.4835 & 0.1006 & 0.1674 \\
\hline
\end{tabular}

Notes. $p$ statistics are in parentheses. ${ }^{* * *} p<0.01,{ }^{* *} p<0.05$, and ${ }^{*} p<0.1$.

political factors, and the increase in holdings is probably not entirely motivated by financial motives [56, 57]. The nature of the property rights of state-owned enterprises has brought political advantages, making them insufficiently pay attention to efficiency and risk [58, 59]. Therefore, block shareholders of state-owned firms are less willing to obtain economic benefits through increased shareholding
[60]. The data on the increase of holdings by block shareholders of Chinese listed companies also showed that the increase of holdings by block shareholders of stateowned enterprises is very consistent with the coordination of government policies, while block shareholders of privately owned enterprises mostly increase their holdings for economic benefits [57]. 
The motivation of the increasing holdings of block shareholders of non-state-owned listed companies are economic factors mostly; while the majority of state-owned companies' block shareholders increase their holdings to cater to or respond to the call of national policies [51], that is, block shareholders increase their shareholdings due to political factors mostly. When the size of GRQ is different, will the size of GRQ make the difference when we consider the difference between state-owned firms and privately owned firms?

Among the 2625 observations, Table 10 uses Model 2 to verify the different results of state-owned listed companies and non-state-owned listed companies. Among them, columns (1) and (2) reflect that when state-owned listed companies recognize different degrees of GR, SI is not significant. However, columns (3) and (4) reflect that SI has increased significantly with the increase in GRQ in non-state-owned listed companies. Since GR is a positive signal of the company's future performance, block shareholders of state-owned listed companies do not need to increase their holdings based on political motives. Table 10 verifies the political motivation of the increasing holdings of block shareholders of state-owned companies, and the economic motivation of the increasing holdings of block shareholders of non-state-owned listed companies. It also verifies the signalling motives of the increasing holdings of block shareholders further. Table 11 presents the empirical results of difference between state-owned firms and private-owned firms in regard to the influence of GI. It appears that when we run subsample regression, GI has no significant influence on block shareholders' behaviour.

\section{Conclusions}

In recent years, China's A-share market has shown the typical characteristics of high goodwill and high GI/total assets or GI/net assets, which have brought fierce discussions on goodwill risks inside and outside the market. The stock price fluctuations from goodwill risks are threatening the stability of the entire capital market. Therefore, goodwill risk has become the focus of the current work resolving major risks and has become an important issue in the Chinese economy gradually. As an insider of the company, block shareholders usually have the same interest trend with the company, and they have information advantages compared with external investors. External investors are more likely to agree with the company information transmitted by block shareholders. Therefore, the behaviour of the increasing holdings of block shareholders can alleviate the company's goodwill risk effectively by sending positive signals to the outside world. Therefore, our paper focuses on discussing the relationship between GR and SI, and the adjustment mechanism of the degree of GI on SI. On this basis, further research is carried out to verify the different effects of GR on SI from the perspective of property rights heterogeneity. Our research has shown the following:

(1) If goodwill was recognized in the period of $M \& A$, block shareholders were more inclined to increase their shareholdings. The more GRQ in the current period, the stronger SIQ.

(2) When listed companies make provision for GI, only block shareholders tend to increase their shareholdings in the high-impairment group, indicating that block shareholders will significantly and positively adjust the impact of GRQ on SIQ in the higherimpairment companies.

(3) Block shareholders of state-owned listed companies choose to increase their holdings based on political motives and block shareholders of non-state-owned listed companies based on economic motives. During the accounting period of GR, since GR is a positive signal of the company's future performance, block shareholders of state-owned listed companies do not need to increase their holdings based on political motives, while block shareholders of nonstate-owned listed companies have strong economic motivation that strengthens their well-being anticipating and obtains future benefits by increasing their holdings, which verified the signalling motives of the increasing holdings of block shareholders further.

Our findings enriched the relationship between GR, GI, and SI, especially the relationship between the higher degree GI and SI. However, as in all empirical research, our findings have several limitations. Firstly, trading conflicts and COVID-19 might amplify the risk of GR and GI, which might have great influence on accounting rules in regarding of goodwill. In consideration of the relevant requirements of accounting information, firms probably need to carry out the current impairment method of goodwill. But there might be difference in the relation between GR, GI, and block shareholders' behaviour under trading conflicts and COVID-19. Secondly, GR and GI used in the paper may be influenced by the macroeconomics; their changes may be synchronized with SI because of the macroeconomics.

\section{Data Availability}

The data used to support this study are available from the corresponding author upon request.

\section{Conflicts of Interest}

The authors declare that there are no conflicts of interest regarding the publication of this paper.

\section{Acknowledgments}

This research was funded by Liaoning Provincial Social Science Foundation (Grant no. L20BJY048) and Liaoning Provincial Education Department Foundation (Grant no. LJKR0019).

\section{References}

[1] R. Stillman, "Examining antitrust policy towards horizontal mergers," Journal of Financial Economics, vol. 11, no. 1-4, pp. 225-240, 1983. 
[2] G. Andrade, M. Mitchell, and E. Stafford, "New evidence and perspectives on mergers," The Journal of Economic Perspectives, vol. 15, no. 2, pp. 103-120, 2001.

[3] H. N. Seyhun, "Why does aggregate insider trading predict future stock returns," Quarterly Journal of Economics, vol. 107, no. 4, pp. 1303-1331, 1992.

[4] J. E. Finnerty, "Insiders and market efficiency," The Journal of Finance, vol. 31, no. 4, pp. 1141-1148, 1976.

[5] D. Givoly and D. Palmon, "Insider trading and the exploitation of inside information: some empirical evidence," Journal of Business, vol. 58, no. 1, pp. 69-87, 1985.

[6] J. Lakonishok and I. Lee, "Are insider trades informative?" Review of Financial Studies, vol. 14, no. 1, pp. 79-111, 2001.

[7] A. S. Kyle, "Continuous auctions and inside trading," Econometrica, vol. 53, pp. 1315-1335, 1995.

[8] Y. Jiang and X. Zhang, "Research on the market timing ability and its influencing factors in major shareholders' stakeraising for China's listed companies," Economic Management, vol. 35, no. 12, pp. 88-99, 2013.

[9] K. W. Chauvin and M. Hirschey, "Goodwill, profitability, and the market value of the firm," Journal of Accounting and Public Policy, vol. 13, no. 2, pp. 159-180, 1994.

[10] R. Jennings, M. Leclere, and R. B. Thompson, "Goodwill amortization and the usefulness of earnings," Financial Analysts Journal, vol. 57, no. 5, pp. 20-28, 2001.

[11] Guo and R. Yu, "Does goodwill indicate corporate ability of excess earning?" Journal of Beijing Jiaotong University, vol. 15, no. 1, pp. 87-97, 2016.

[12] J. Godfrey and P. S. Koh, "The relevance to firm valuation of capitalising intangible assets in total and by category," Australian Accounting Review, vol. 11, no. 24, pp. 39-48, 2001.

[13] W. Huang and X. Tang, "Influence of M\&A goodwill on firm performance-analysis based on the mediation effect of earnings management and financial constraints," Journal of Shanxi University of Finance and Economics, vol. 41, no. 12, pp. 93-106, 2019.

[14] Z. Wei and C. Zhu, "Does excess goodwill become the burden of corporate operation-explanation from the perspective of product market competitiveness," China's Industrial Economy, vol. 11, pp. 174-192, 2019.

[15] H. Zheng, Z. Liu, and W. Feng, "Can merger and acquisition goodwill promote company performance?-empirical evidence from Chinese A-shares listed companies," Accounting Research, vol. 3, pp. 11-17, 2014.

[16] J. Ye, K. He, and Q. Yang, "Unverifiable estimates in goodwill impairment test and audit fees," Audit Research, vol. 1, pp. 76-84, 2016.

[17] J. Zhang, J. Duan, and Q. Zhang, "Research on M\&A arbitrage theory," Economic Aspect, vol. 3, pp. 42-45, 2010.

[18] H. Pan, X. Rao, and Z. Zhang, "M\&A arbitrage: from the evidence of insiders' shares selling," Economic Management, vol. 41, no. 3, pp. 107-123, 2019.

[19] Y. Wu and S. Wu, "Tunnelling behaviours during large shareholders' stock-selling periods," China's Industrial Economy, vol. 5, pp. 121-130, 2010.

[20] L. Y. Dann, "Common stock repurchases: an analysis of returns to bondholders and stockholders," Journal of Financial Economics, vol. 9, no. 2, pp. 113-138, 1981.

[21] H. Han, Q. Tang, and W. Li, "Goodwill impairment losses, information asymmetry and stock price crash risk," Securities Market Herald, vol. 3, pp. 59-70, 2019.

[22] W. Xu, A. Anandarajan, and A. Curatola, "The value relevance of goodwill impairment," Research in Accounting Regulation, vol. 23, no. 2, pp. 145-148, 2011.
[23] X. Qu, Y. Lu, and R. Zhang, "Value relevance of goodwill impairments: empirical evidence from Chinese A-share market," Economics and Management Research, vol. 38, no. 3, pp. 122-132, 2017.

[24] T. Lu and J. Sun, "The goodwill risk of listed companies' mergers and acquisitions," China Finance, vol. 10, pp. 69-71, 2017.

[25] A. Lin and D. Yang, "Goodwill impairment, stock liquidity and corporate value," Journal of China University of Mining \& Technology (Social Science Edition), vol. 23, pp. 1-17, 2021.

[26] J. Francis, J. D. Hanna, and L. Vincent, "Causes and effects of discretionary asset write-offs," Journal of Accounting Research, vol. 34, pp. 117-134, 1996.

[27] A. Schatt, L. Doukakis, and C. Bessieux-Ollier, "Do goodwill impairments by European firms provide useful information to investors?" Accounting in Europe, vol. 13, no. 3, pp. 307-327, 2016.

[28] K. Ramanna and R. L. Watts, "Evidence on the use of unverifiable estimates in required goodwill impairment," Review of Accounting Studies, vol. 17, no. 4, pp. 749-780, 2012.

[29] K. K. Li and R. G. Sloan, "Has goodwill accounting gone gad?" Review of Accounting Studies, vol. 22, no. 2, pp. 964-1003, 2017.

[30] R. Ge and C. S. Lennox, "Do acquirers disclose good news or withhold bad news when they finance their acquisitions using equity?" Review of Accounting Studies, vol. 16, no. 1, pp. 183-217, 2011.

[31] Q. Tang and H. Han, "Related party M\&as and firm value: the governance effect of accounting conservatism," Nankai Management Review, vol. 21, no. 3, pp. 23-34, 2018.

[32] Y. Xu and X. Guo, "The research on the prediction effects of executive trading behaviours on acquisition performance," Securities Market Herald, vol. 10, pp. 4-10, 2016.

[33] A. Shleifer and R. W. Vishny, "A survey of corporate governance," The Journal of Finance, vol. 52, no. 2, pp. 737-783, 1997.

[34] Y. Liu, "Research on the development characteristics and market significance of large shareholders' holding increase in listed companies," China Securities Futures, vol. 1, pp. 17-18, 2012.

[35] W. P. Dukes, C. J. Frohlich, and C. K. Ma, "Risk arbitrage in tender offers," Journal of Portfolio Management, vol. 18, no. 4, pp. 47-55, 1992.

[36] J. Jindra and R. A. Walkling, "Speculation spreads and the market pricing of proposed acquisitions," Journal of Corporate Finance, vol. 10, no. 4, pp. 495-526, 2004.

[37] M. E. Olante, "Overpaid acquisitions and goodwill impairment losses-evidence from the US," Advances in Accounting, vol. 29, no. 2, pp. 243-254, 2013.

[38] D. Li, J. Ye, and S. Lu, "Management overconfidence, nature of property rights and goodwill from M\&A activities," Accounting Research, vol. 10, pp. 50-57, 2018.

[39] J. Chen, H. Hong, and J. Stein, "Forecasting crashes: trading volume, past returns, and conditional skewness in stock prices," Journal of Financial Economics, vol. 61, no. 3, pp. 345-381, 2001.

[40] S. P. Kothari, S. Shu, and P. D. Wysocki, "Do managers withhold bad news?" Journal of Accounting Research, vol. 47, no. 1, pp. 241-276, 2009.

[41] B. L. Connelly, S. T. Certo, and R. D. Ireland, "Signalling theory: a review and assessment," Journal of Management, vol. 37, no. 1, pp. 39-67, 2011. 
[42] D. Ikenberry, J. Lakonishok, and T. Vermaelen, "Market underreaction to open market share repurchases," Journal of Financial Economics, vol. 39, no. 2-3, pp. 181-208, 1995.

[43] K. B. Huddart, "Information asymmetry and cross-sectional variation in insider trading," Contemporary Accounting Research, vol. 24, pp. 195-232, 2007.

[44] M. Deng and C. Mei, "The sword of damocles hanging over the head of high-premium mergers and acquisitions: goodwill and stock price crash risk," Financial Economics Research, vol. 34, no. 6, pp. 56-69, 2019.

[45] F. Hu and K. Li, "Overvaluation and goodwill impairment," Financial Research, vol. 45, no. 6, pp. 71-85, 2019.

[46] Limmack and J. Robin, "Discussion of an examination of the long run performance of UK acquiring firms," Journal of Business Finance \& Accounting, vol. 24, pp. 1003-1007, 1997.

[47] C. Hu, F. Zhu, and H. Qiu, "Share pledges, risk management, and stake raising by large shareholders," Financial Research, vol. 9, pp. 190-206, 2020.

[48] S. Tang, D. Wen, and L. Zhao, "The motives and effects of large shareholders' increase in shareholdings," Financial Research, vol. 40, no. 12, pp. 4-14, 2014.

[49] H. Yu and Z. Wang, "Financial performance, controlling ability of major shareholders and major shareholders' holding increase behavior: empirical evidence from major shareholders' increase of stocks in my country's shanghai and shenzhen stock markets," Accounting Communications, vol. 33, pp. 72-74, 2010.

[50] X. Li, Y. Xue, and J. Zhou, "CEO connectedness, internal governance and corporate performance," Management Science, vol. 30, no. 5, pp. 102-118, 2017.

[51] B. Wang, M. Lv, and W. Su, "Research on governance effects of the internal auditors as members of the board of supervisors," Nankai Management Review, vol. 21, no. 3, pp. 76-89, 2018.

[52] R. Lu and X. Sun, "Institutional investors' preference for concept stocks and the stock market bubble riding," China's Industrial Economy, vol. 3, pp. 174-192, 2021.

[53] Z. Xu and Y. Huang, "Research on the control rights and financing structure of start-ups," Finance and Accounting Monthly, vol. 27, pp. 37-44, 2017.

[54] J. Brogaard, L. Dan, and X. Ying, "Stock liquidity and default risk," Journal of Financial Economics, vol. 124, no. 3, pp. 486-502, 2017.

[55] Q. Chen and Y. Bian, "Check-and-balance ownership structure, agency costs and enterprise performance: empirical analysis of China's private A-share listed companies," Scientific Decision, vol. 5, pp. 74-92, 2015.

[56] Y. F. Shen, W. H. Cu, and P. G. li, "Stake-raising: financial motivation vs. political motivation," Accounting Research, vol. 1, pp. 52-59, 2011.

[57] S. Tang, D. R. Wen, L. Y. Zhao, and Y. Liu, "The motives and effects of large shareholders' increase in shareholdings," Journal of Finance and Economics, vol. 40, no. 12, pp. 4-14, 2014.

[58] M. Q. Sheng, M. Zhang, L. J. Ma, and H. Li, "State ownership, budget control and dynamic adjustment of capital structure," Management World, vol. 3, pp. 151-157, 2013.

[59] R. M. Liu, "Efficiency of Chinese state-owned firms: a literature review," Journal of World Economy, vol. 36, no. 33, pp. 136-160, 2013.

[60] B. Y. Ren and K. C. Yang, "Motivation of large shareholders' stake-raising: timing or self-protection? Evidence based on equity pledge," Research on Financial and Economics Issues, vol. 9, pp. 68-75, 2018. 